\title{
A study of Smad4, Smad6 and Smad7 in Surgically Resected Samples of Pancreatic Ductal Adenocarcinoma and Their Correlation with Clinicopathological Parameters and Patient Survival
}

\author{
Puneet Singh ${ }^{1 *}$, Radhika Srinivasan², Jai Dev Wig ${ }^{1}$ and Bishan Das Radotra ${ }^{3}$
}

\begin{abstract}
Background: Smad4 is the common mediator of the tumor suppressive functions of TGF-beta. Smad6 and Smad7 are the antagonists of the TGF-beta pathway. This study investigates the differential protein expressions of Smad4, Smad6 and Smad7 in tumor as compared to normal tissue of pancreatic ductal adenocarcinoma (PDAC) and compares them with clinicopathological parameters and patient survival.

Results: There was a significant difference in protein expressions of Smad4 ( $p=0.0001)$, Smad6 $(p=0.0015)$ and Smad7 ( $p=0.0005$ ) protein in tumor as compared to paired normal samples. Loss of Smad7 expression correlated significantly with tumor size $(r=0.421, p<0.036)$ and margin status $(r=0.431 ; p<.032)$. Patients with moderate to high Smad4 protein expression had a better survival (median survival $=14.600 \pm 2.112$ months) than patients with absent or weak Smad4 protein expression (median survival $=7.150 \pm 0.662$ ). In addition, advanced disease stage correlated significantly with poor prognosis.

Conclusion: Loss of Smad4 significantly correlated with poor survival of PDAC patients. In the cases where Smad4 is expressed, Smad6 inhibition is possibly a novel mechanism for Smad4 inactivation. Smad7 has a role in pathobiology of PDAC. Further investigation in the roles of Smad6 and Smad7 would help in the identification of novel therapeutic targets for PDAC.
\end{abstract}

Keywords: Pancreas, pancreatic adenocarcinoma, Smad4, Smad6, Smad7, clinicopathological parameters, prognosis

\section{Background}

Smad proteins are a family of intracellular mediators of the transforming growth factor beta (TGF- $\beta$ ) family of cytokines. On ligand binding, TGF- $\beta$ Receptor II (T $\beta$ RII) becomes constitutively active, heterodimerizes with TGF- $\beta$ Receptor I (T $\beta$ RI) and transphosphorylates its GS domain resulting in its activation [1,2]. Once activated, T $\beta R I$ phosphorylates a class of molecules known as receptor-regulated Smads (R-Smads), Smad2 and Smad3, at an SSXS motif at their C-terminal end [3].

\footnotetext{
* Correspondence: puneetsingh@sydney.edu.au

'Department of General Surgery, Postgraduate Institute of Medical Education and Research, Chandigarh, India

Full list of author information is available at the end of the article
}

Active, phosphorylated R-Smads heterodimerize with common-Smad (Co-Smad), Smad4, translocate to the nucleus and regulate gene expression [4,5]. A third class of Smad proteins, the inhibitory Smads (I-Smads), Smad6 and Smad7 act as negative regulators and act by blocking R-Smads' interaction with T $\beta$ RI, phosphorylation by T $\beta R I$ or heterodimerization with Smad4 $[6,7]$.

Smad4 is being explored as one of the major molecular markers in pancreatic ductal adenocarcinoma (PDAC) (as reviewed by [8]). Although lost in many cancers, loss of Smad4 is more sensitive and specific to pancreatic cancer [9]. Studies have shown SMAD4 gene to be inactivated in $55 \%$ of pancreatic cancers [10-12]. The inactivation of SMAD4 gene occurs either by

\section{() Biomed Central}


deletion of both alleles (35\%) or by intra-genic mutation in one allele coupled with the loss of the other allele (20\%) [13]. A number of studies demonstrate the role of Smad4 in pancreatic ductal adenocarcinoma, but only a few studies have explored the roles of inhibitory Smads, Smad6 and Smad7 in this disease (as reviewed by [14]).

In the present study, we examined the differential protein expressions of Smad4, Smad6 and Smad7 in surgically resected samples of paired tumor tissue of pancreatic ductal adenocarcinoma versus adjacent normal tissue. A combinatorial expression of these three Smads was evaluated to gain an insight into how they influenced one another in pancreatic ductal adenocarcinoma as compared to normal pancreas. Influence of the expression levels of these proteins on clinicopathological parameters and patient survival was studied.

\section{Methods \\ Patients}

The study was conducted after obtaining a formal approval from the Ethics Committee of the Postgraduate Institute of Medical Education and Research. Informed oral consent was obtained from each patient for participation in the study.

Twenty-five prospective cases of histopathologically proven pancreatic ductal adenocarcinoma, collected over a period of 36 months at the Department of General Surgery, Postgraduate Institute of Medical Education and Research, Chandigarh, India, were included in our study. Out of these 25 subjects, 13 were males and 12 were females. The mean age of the patients was 54.6 years, with two patients below 40 and one as young as 28 . Follow-up data was collected for all patients. Most PDAC tumor samples were either highly differentiated (13) or moderately differentiated (11), with just one case poorly differentiated. The patients were staged according to the Tumor, Node and Metastasis (TNM) classification of the International Union against Cancer [15]. Clinicopathological and outcome data is summarized in Table 1.

\section{Tissue Sample}

Surgically resected samples were collected and tumor was confirmed by performing hematoxylin and eosin (H\&E) staining on frozen sections taken on autoclaved glass slides. Similarly, the presence of normal pathology in the adjacent normal tissues was also confirmed. Initially, samples from a total of 32 consecutive patients were collected, out of which 25 samples that showed tumor tissue in more than $90 \%$ of the area of the section were included for study. Part of the samples to be used for immunohistochemistry were formalin fixed, and part of them were snap frozen and stored at $-80^{\circ} \mathrm{C}$ for further molecular analysis.
Table 1 Clinical profile of patients with pancreatic ductal adenocarcinoma $(n=25)$

\begin{tabular}{|c|c|c|}
\hline Clinical variable & Groups & No. of patients \\
\hline \multirow[t]{2}{*}{ Age (range 28-75) } & $<50$ & $5(20 \%)$ \\
\hline & $\geq 50$ & $20(80 \%)$ \\
\hline \multirow[t]{2}{*}{ Sex } & Male & $13(52 \%)$ \\
\hline & Female & $12(48 \%)$ \\
\hline \multirow[t]{4}{*}{ Stage } & I & $3(12 \%)$ \\
\hline & $\|$ & $7(28 \%)$ \\
\hline & III & $14(64 \%)$ \\
\hline & IV & $1(4 \%)$ \\
\hline \multirow[t]{2}{*}{ Grade } & Well differentiated & $13(52 \%)$ \\
\hline & Moderately/poorly differentiated & $12(48 \%)$ \\
\hline \multirow[t]{2}{*}{ Tumor size } & $<3 \mathrm{~cm}$ & $19(76 \%)$ \\
\hline & $\geq 3 \mathrm{~cm}$ & $6(24 \%)$ \\
\hline \multirow[t]{2}{*}{ Margin status } & Positive & $3(12 \%)$ \\
\hline & Negative & $22(88 \%)$ \\
\hline \multirow[t]{2}{*}{ Lymph Node status } & Positive & $6(24 \%)$ \\
\hline & Negative & $19(76 \%)$ \\
\hline
\end{tabular}

\section{Clinicopathological Data}

Clinical and pathological data were obtained from the patients' medical records. Clinical and pathological variables included age, gender, tumor size, margin status, stage, grade, and survival.

\section{Immunohistochemistry}

Immunohistochemical labeling was done on $4 \mu \mathrm{m}$ tissue sections mounted on slides coated with poly-Llysine (Sigma, St. Louis, Missouri, USA) using the routine streptavidin - biotin immunoperoxidase technique. Sections were deparaffinised in xylene, rehydrated through a series of graded alcohol to distilled water and microwaved in buffered sodium citrate. Endogenous peroxidase was blocked by incubating in hydrogen peroxidase with methanol followed by overnight incubation with monoclonal antibodies, anti-Smad4 (clone B-8), anti-Smad6 (clone H-150) and anti-Smad7 (clone H-79), obtained from Santa Cruz Biotechnology Inc., Santa Cruz, California, USA. Novastatin Universal Detection kit (Ready to use, Novacastra Laboratories Ltd., Newcastle, UK) containing biotinylated secondary antibody was applied and staining was visualised using 3', 3'- Diaminobenzidinetetrahydrochloride (Sigma Chemical Co., St. Louis, USA) solution as the chromogen. The sections were counterstained in Mayer's haematoxylin, rinsed in water, and mounted in Di-NButyle Phthalate in Xylene. The brown product obtained was visualized and scored by light microscopy. Antigen retrieval conditions and the antibody dilutions used are summarized in Table 2. 
Table 2 Antibodies used in the study

\begin{tabular}{ccccc}
\hline Antibody & Clone* & Antigen retrieval & Primary antibody incubation & Concentrations used \\
\hline anti-Smad4 & Clone B-8 & Pressure cooker for 20 min & $2 \mathrm{~h}$ at room temperature & $2 \mu \mathrm{g} / \mathrm{ml}(1: 100)$ \\
\hline anti-Smad6 & Clone H-150 & Microwaving:3 Cycles 3 min +1 Cycle $1 \mathrm{~min}$ & Overnight at 4 ${ }^{\circ} \mathrm{C}$ & $4 \mu \mathrm{g} / \mathrm{ml}(1: 50)$ \\
\hline anti-Smad7 & Clone H-79 & Microwaving: 3 Cycles 3 min +1 Cycle 1 min & Overnight at 4 ${ }^{\circ} \mathrm{C}$ & $4 \mu \mathrm{g} / \mathrm{ml}(1: 50)$ \\
\hline
\end{tabular}

*All antibodies were obtained from Santa Cruz Biotechnology Inc., CA., USA.

\section{Immunohistochemical Evaluation}

Immunohistochemical scoring was done independently by two senior cytopathologists (BDR and RS) and only samples with complete concordance in staining and histopathology were included in the study. The slides were scored as follows: 0 (no staining), 1+ (weak staining), 2+ (moderate staining), and $3+$ (strong staining), a scoring system previously described by Hua et al [16]. Paired adjacent normal tissue samples served as positive controls for each of the cases. There was a complete concordance in all the cases except one, where high and moderate expression of Smad4 for the same normal tissue sample was respectively reported. Re-evaluation, however, eliminated the discrepancy.

\section{Statistical Methods}

Fisher's exact test was used to compare Smad4, Smad6 and Smad7 protein expression in normal and tumor tissue. Spearman rank correlation test was used to correlate Smad4, Smad6 and Smad7 protein expression in tumor tissue with clinicopathological parameters. Kaplan-Meier survival analysis was used to analyse the influence of Smad4, Smad6 and Smad7 protein expression in tumor tissue and clinicopathological parameters on survival. A probability value of less than 0.05 was considered to be significant.

\section{Results}

Immunohistochemical expression of Smad4, Smad6 and Smad7

Protein levels of all three Smads, Smad4, Smad6 and Smad7 were evaluated in paired normal pancreatic tissues and tumor samples of pancreatic ductal adenocarcinoma (Figure 1; Table 3). A comparison of the protein levels between normal and tumor tissues for each of the three Smads is shown in Figure 2.

\section{Smad4}

Smad4 showed cytoplasmic as well as nuclear staining, which was both diffuse and focal (Figure 1a, b). Most normal tissue showed strong to moderate Smad4 immunoreactivity $(24 / 25,96 \%)$, whereas most tumor tissue showed absent $(10 / 25,40 \%)$ or weak $(10 / 25,40 \%)$ immunoreactivity for Smad4. Strong to moderate expression was seen only in $20 \%(5 / 25)$ of tumor samples. The difference in Smad4 protein levels in tumor tissue as compared to normal pancreatic tissue was highly significant on Fisher's exact test (two tailed p value $=0.0001)$.

\section{Smad6}

The protein immunoreactivity was predominantly cytoplasmic (Figure 1c, d). Here also, most of the normal tissues showed strong $(18 / 25,72 \%)$ to moderate $(5 / 25$, $20 \%)$ immunopositivity. However, A good number (12/ $25,48 \%$ ) of tumor tissues showed moderate levels of Smad6 protein expression, in contrast to Smad4 where

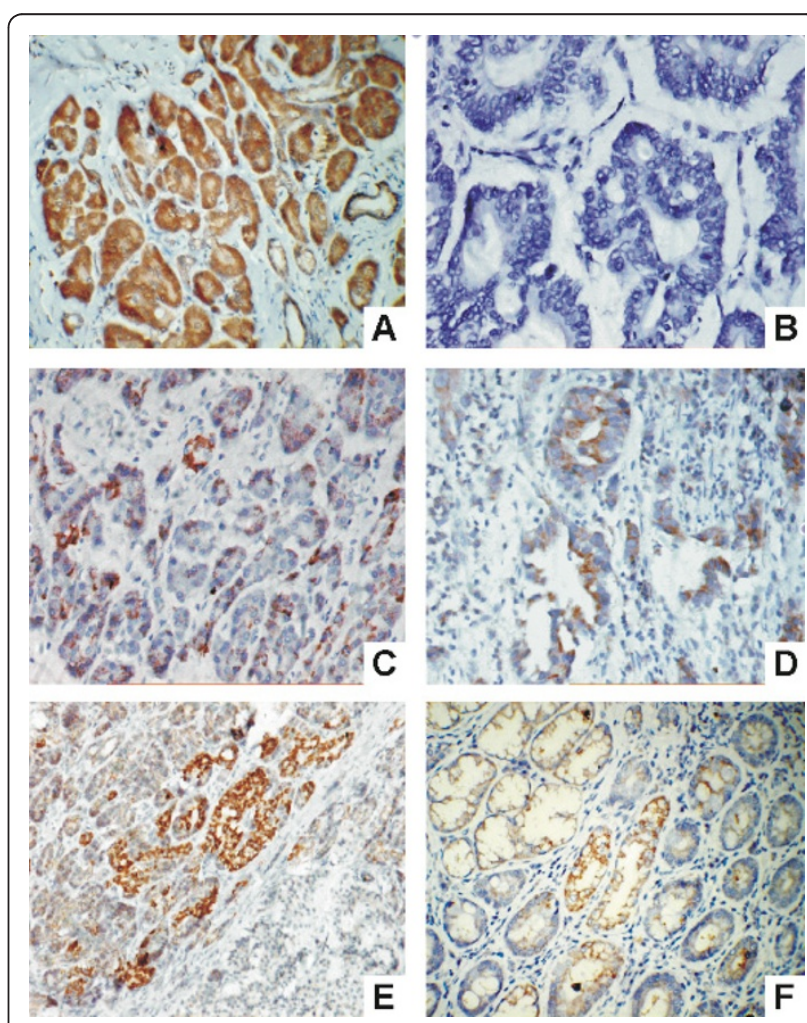

Figure $1 \mathrm{Immunohistochemistry} \mathrm{for} \mathrm{Smads} \mathrm{in} \mathrm{paired} \mathrm{tumor}$ and normal pancreatic tissues. Upper panel shows the normal pancreatic tissue and the down panel shows the corresponding tumor tissue. Normal pancreas with strong focal and nuclear positivity (a. $\times 100)$ and tumor negative for Smad4 (b. $\times 400)$. Normal pancreas with strong diffuse cytoplasmic positivity $(c . \times 100)$ and tumor with moderate focal cytoplasmic positivity for Smad6 (d. $\times 200$ ). Normal pancreas with strong diffuse cytoplasmic positivity (e. $\times 100$ ) and tumor negative for Smad7 protein (f. $\times 200$ ). (streptavidinbiotin immunoperoxidase). 
Table 3 Immunohistochemical expression of Smad4, Smad6 \& Smad7 in paired samples of Normal pancreas and Pancreatic ductal adenocarcinoma $(n=25)$

\begin{tabular}{ccccccc}
\hline IHC Score & \multicolumn{2}{c}{ Smad4 } & \multicolumn{2}{c}{ Smad6 } & \multicolumn{2}{c}{ Smad7 } \\
\cline { 2 - 7 } & Normal & Tumor & Normal & Tumor & Normal & Tumor \\
\hline 0 & $1(4 \%)$ & $10(40 \%)$ & $1(4 \%)$ & $7(28 \%)$ & $3(12 \%)$ & $14(56 \%)$ \\
\hline $1+$ & $0(0 \%)$ & $10(40 \%)$ & $1(4 \%)$ & $6(24 \%)$ & $4(16 \%)$ & $6(24 \%)$ \\
\hline $2+$ & $8(32 \%)$ & $5(20 \%)$ & $5(20 \%)$ & $12(48 \%)$ & $8(32 \%)$ & $4(16 \%)$ \\
\hline $3+$ & $16(64 \%)$ & $0(0 \%)$ & $18(72 \%)$ & $0(0 \%)$ & $10(40 \%)$ & $1(4 \%)$ \\
\hline
\end{tabular}

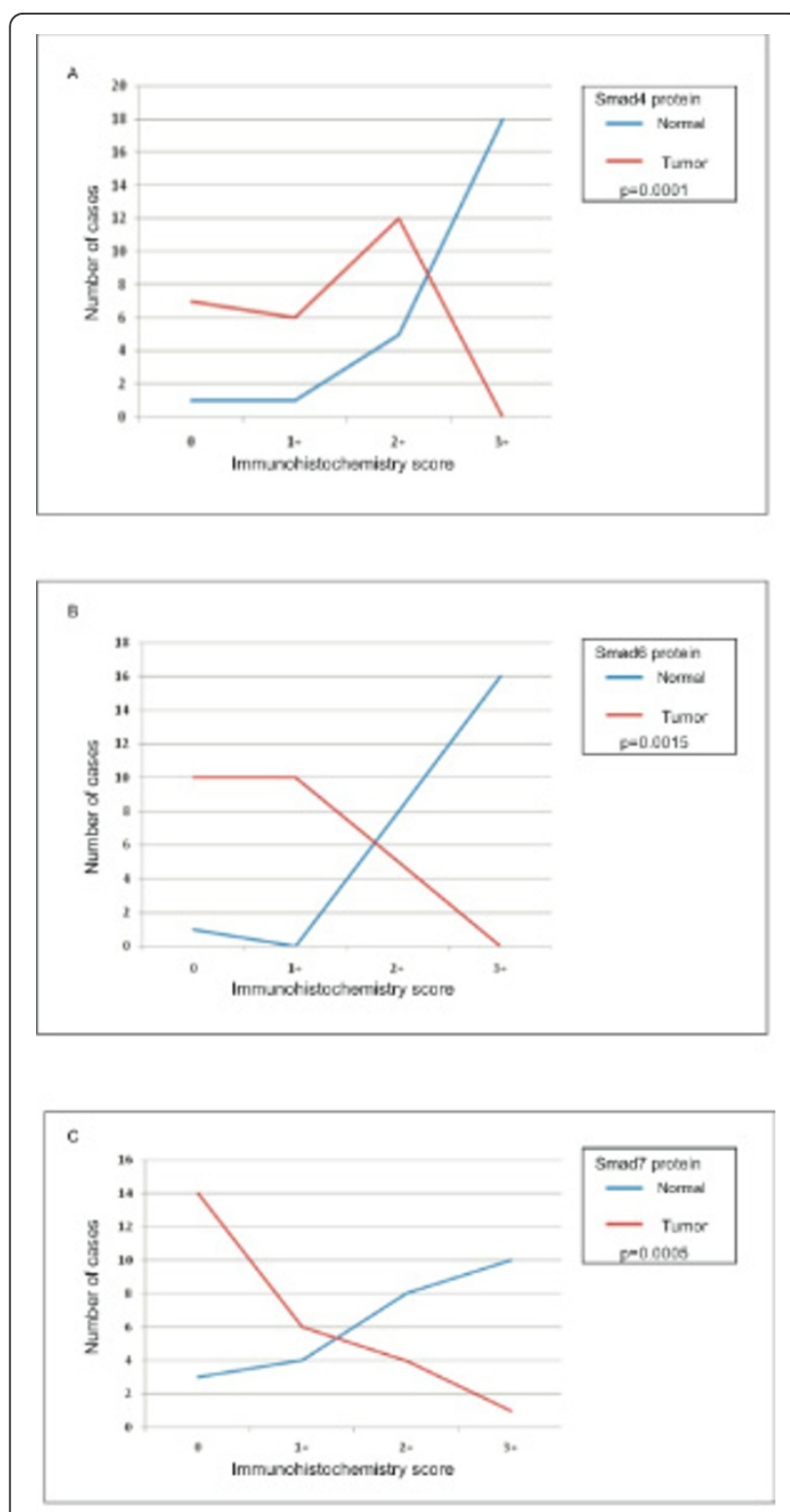

Figure 2 Frequency of protein expression in normal pancreas and pancreatic ductal adenocarcinomas for Smad4, Smad6 and Smad7, respectively. The $x$-axis represents the immunohistochemistry score and $y$-axis represents the number of cases. most of the cases were weakly positive or absent. Complete loss of Smad6 expression was seen only in 28\%(7/ 25) of tumor cases. The difference in Smad6 protein levels in tumor tissue as compared to normal pancreatic tissue was highly significant by Fisher's exact test $(\mathrm{p}=$ 0.0015).

\section{Smad7}

The immunoreactivity was predominantly cytoplasmic, although occasional nuclear positivity was obtained in some normal pancreatic ducts (Figure 1e, f). Similar to Smad4, normal pancreatic tissue showed moderate to high levels of Smad7 expression in most of the samples $(18 / 25,72 \%)$, whereas, more than half of tumor tissue showed complete loss of protein expression $(4 / 25,56 \%)$, and another $24 \%(6 / 25)$ of cases showed low expression. The difference in the expression levels of Smad7 in normal pancreatic samples as compared to tumor samples was highly significant by Fisher's exact test $(\mathrm{p}=0.0005)$.

\section{Co-expression of Smad4 with inhibitory Smads}

In tumor samples, out of $15 \mathrm{Smad} 4$ positive cases, 10 showed low and 5 showed moderate Smad4 protein expression. In four out of these five cases, either or both Smad6 and Smad7 were moderately co-expressed. Overall, out of 15 Smad4 positive cases, 14 cases showed either Smad6 or Smad7 expression, with almost all cases except one showing Smad6 expression (Table 4).

\section{Correlation of Smad4, Smad6 and Smad7 protein} expression with clinocopathological parameters

A comparison of various clinicopathological parameters with Smad4, Smad6 and Smad7 protein expressions using Spearman correlation was done (Table 5). Absent/ low Smad7 protein expression showed a significant positive correlation with tumour size $(\mathrm{r}=0.421, \mathrm{p}<.036)$ and margin status $(\mathrm{r}=0.431 ; \mathrm{p}<.032)$.

\section{Univariate analysis for survival}

The mean $( \pm$ SEM) survival of patients was $8.64 \pm 4.5$ months and the median survival was 9 months. $20 \%$ of patients survived over one year. Kaplan-Meier analysis for survival demonstrated that patients with moderate to high Smad4 protein expression had a better survival (median survival $=14.600 \pm 2.112$ months) than patients with absent or weak Smad4 protein expression (median survival $=7.150 \pm 0.662)[\log$ Rank (Mantel-Cox) Chi Square 9.116, significance .003] (Figure 3, Table 6). Even on adjusting individually for the stage, tumor size, grade and margin status of PDAC tumor samples, moderate to high Smad4 protein expression positively influences survival significantly [Log Rank (Mantel-Cox) Chi-Square 8.250, significance .004; Log Rank (Mantel-Cox) ChiSquare 9.772, significance .002; Log Rank (Mantel-Cox) 
Table 4 Combinatorial expression of Smad4, Smad6 \& Smad7 in 25 tumor samples of pancreatic ductal adenocarcinoma patients

\begin{tabular}{ccccc}
\hline & \multicolumn{4}{c}{ Positive cases } \\
\cline { 2 - 5 } & $\begin{array}{c}\text { Smad6 } \\
(\mathbf{n}=\mathbf{1 8}, \mathbf{7 2 . 0} \%)\end{array}$ & $\begin{array}{c}\text { Smad7 } \\
(\mathbf{n}=\mathbf{1 1}, \mathbf{4 4 . 0 \% )}\end{array}$ & $\begin{array}{c}\text { Smad6 or Smad7 } \\
(\mathbf{n}=\mathbf{2 1}, \mathbf{8 4 . 0 5})\end{array}$ & $\begin{array}{c}\text { Smad6 and Smad7 } \\
(\mathbf{n}=\mathbf{9}, \mathbf{3 6 \%})\end{array}$ \\
\hline Smad4 positive cases $(\mathbf{n}=\mathbf{1 5})$ & $14(93.3 \%)$ & $9(60.0 \%)$ & $15(100 \%)$ & $5(55.5 \%)$ \\
\hline Smad4 negative cases $(\mathbf{n}=\mathbf{1 0})$ & $4(40.0 \%)$ & $2(20.0 \%)$ & $9(90.0 \%)$ & $4(44.5 \%)$ \\
\hline
\end{tabular}

Chi-Square 9.377, significance .002; Log Rank (MantelCox) Chi-Square 8.524, significance .004]. Smad 6 and Smad 7 protein expression did not influence survival. Stage I \& II patients showed a longer survival (median survival $10 \pm 2.066$ months) as compared to those in Stage III \& IV (median survival $7 \pm .949$ months) [Log Rank (Mantel-Cox) Chi-Square 4.644, significance .031] (Figure 3, Table 6).

\section{Discussion}

Smad4 is the common mediator of the tumor suppressive functions of TGF-beta. Smad6 and Smad7 are antagonists of the TGF-beta pathway. In this work, we further establish the role of Smad4 as a potential prognostic marker for pancreatic ductal adenocarcinoma. We also identified different roles for Smad6 and Smad7 in influencing pancreatic cancer biology.

In this study, Smad4 was expressed in most of the normal samples (96\%) but lost in $40 \%$ of tumor samples. In tumor samples, even where it was expressed, there was weak expression in the majority of cases. Kaplan-
Meier analysis for survival demonstrated that patients with moderate Smad4 protein expression had a better survival than patients with weak or negative Smad4 protein expression. Despite one report of Smad4 expression to be inversely related to survival in surgically resected pancreatic ductal adenocarcinoma patients [17], there is growing evidence for the correlation of Smad4 status to patient survival in this disease $[16,18]$. One study also correlated the Smad4 expression with the pattern of disease progression (local $\mathrm{v}$ distant dominant) and proposed to further explore its role as a predictive biomarker for personalized treatment strategies [19]. Our observations further adds to preexisting data and establish Smad4 as a potential prognostic marker for pancreatic ductal adenocarcinoma. However, a recent meta-analysis analyzing 5 studies evaluating Smad4 could not find any significant overall association between Smad4 expression and survival [20]. This indicates difficulty in making a reliable conclusion regarding the relative prognostic value of immunohistochemical markers when analyzed in a limited patient series.

Table 5 Correlations of the expression of Smad4, Smad6 and Smad7 with clinicopathological parameters in 25 patients of pancreatic ductal adenocarcinoma

\begin{tabular}{|c|c|c|c|c|c|c|c|c|}
\hline Parameters & Groups & $\begin{array}{l}\text { No. } \\
\text { (n) }\end{array}$ & $\begin{array}{l}\text { Loss/low expression of } \\
\text { Smad4 (\%) }\end{array}$ & $\begin{array}{l}P \\
\text { value } \\
(2- \\
\text { tailed) }\end{array}$ & $\begin{array}{l}\text { Loss/low expression of } \\
\text { Smad } 6(\%)\end{array}$ & $\begin{array}{l}P \\
\text { value }\end{array}$ & $\begin{array}{l}\text { Loss/low expression of } \\
\text { Smad7(\%) }\end{array}$ & $\begin{array}{l}P \\
\text { value }\end{array}$ \\
\hline \multirow[t]{2}{*}{ Age } & $<50$ & 5 & $4(16 \%)$ & 1.000 & $4(16 \%)$ & 0.244 & $4(16 \%)$ & 1.000 \\
\hline & $\geq 50$ & 20 & $16(40 \%)$ & & $10(40 \%)$ & & 16 (64\%) & \\
\hline \multirow[t]{2}{*}{ Sex } & Male & 13 & $10(40 \%)$ & 0.704 & $7(28 \%)$ & 0.830 & $10(40 \%)$ & 0.704 \\
\hline & Female & 12 & $10(40 \%)$ & & $7(28 \%)$ & & $10(40 \%)$ & \\
\hline \multirow[t]{2}{*}{ Grade } & G1 & 13 & $11(44 \%)$ & 0.567 & $8(32 \%)$ & 0.580 & $9(36 \%)$ & 0.175 \\
\hline & G2 & 12 & $9(36 \%)$ & & $6(24 \%)$ & & $11(44 \%)$ & \\
\hline \multirow[t]{2}{*}{ Stage } & $I+\|$ & 10 & $7(28 \%)$ & 0.328 & $5(20 \%)$ & 0.639 & $8(32 \%)$ & 1.000 \\
\hline & III+IV & 15 & $13(52 \%)$ & & $9(36 \%)$ & & $12(48 \%)$ & \\
\hline \multirow[t]{2}{*}{ LN status } & Negative & 19 & $15(60 \%)$ & 0.824 & $9(36 \%)$ & 0.132 & $15(60 \%)$ & 0.824 \\
\hline & Positive & 6 & $5(20 \%)$ & & $5(20 \%)$ & & $5(20 \%)$ & \\
\hline \multirow[t]{2}{*}{ Tumor size } & $<3 \mathrm{~cm}$ & 19 & $16(64 \%)$ & 0.370 & $11(44 \%)$ & 0.747 & $17(68 \%)$ & $0.036^{*}$ \\
\hline & $\geq 3 \mathrm{~cm}$ & 6 & $4(16 \%)$ & & $3(12 \%)$ & & $3(12 \%)$ & \\
\hline \multirow{2}{*}{$\begin{array}{l}\text { Margin } \\
\text { status }\end{array}$} & Positive & 3 & $2(8 \%)$ & 0.558 & $1(4 \%)$ & 0.420 & $1(4 \%)$ & $0.032^{*}$ \\
\hline & Negative & 22 & $18(72 \%)$ & & $13(52 \%)$ & & $19(76 \%)$ & \\
\hline
\end{tabular}



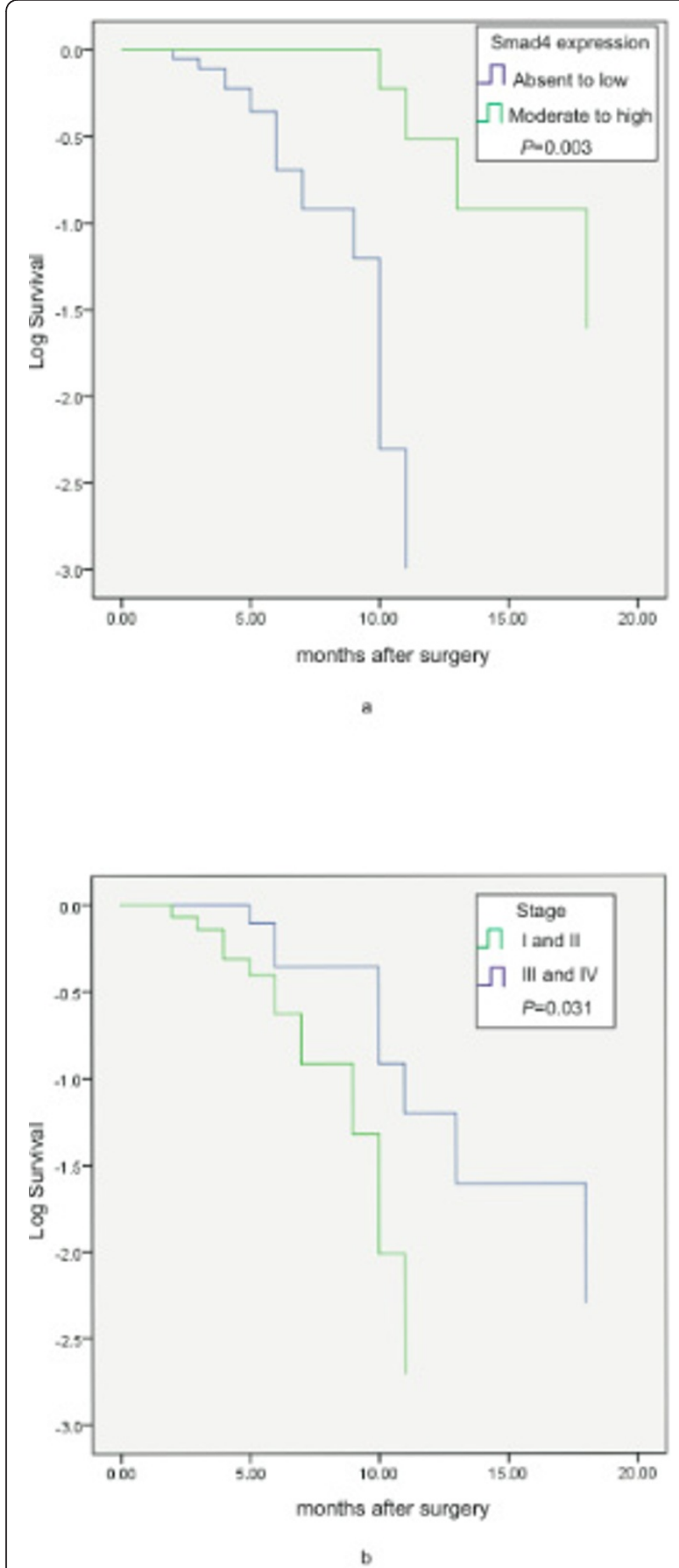

Figure 3 Kaplan-Meier plot for disease specific survival: according to Smad4 protein expression (a.) and according to Stage of pancreatic ductal adenocarcinoma (early: I + II; advanced: III + IV) (b.).

For Smad6 and Smad7, although occasional samples showed nuclear staining, cytoplasmic staining was predominant. Previous reports have shown that while Smad7 appears to reside predominantly in the nucleus at basal state, it translocates to the cytoplasm upon TGF- $\beta$ stimulation [21]. The cytoplasmic staining of Smad6 and Smad7 in most samples implies that these two inhibitory Smads were in their activated states in most tumor samples.

There are just two reports on Smad6 expression in pancreatic cancer till date. One of them conducted in pancreatic cancer cell line, found Smad6 and Smad7 levels to be elevated in pancreatic cancer [22]. The second study, conducted on patient samples, contradicts this and demonstrates that the increased expressions of either Smad6 or Smad7 are infrequent in tumor compared to normal samples [23]. Our study goes a step further, and shows that Smad6 as well as Smad7 are lost in tumor as compared to normal samples. We showed a loss of expression of Smad6 in 28\% tumor samples as compared to $8 \%$ loss in normal samples. In cases where Smad6 was expressed, the expression was mostly moderate to high. Its cytoplasmic staining, along with its co expression with Smad4 in 14 out of 15 Smad4 positive cases suggests that Smad6 can be one of the possible inhibitory mechanisms for Smad4 inactivation. Thus, in pancreatic ductal adenocarcinoma cases where Smad4 itself is not lost, we illustrate a novel mechanism for its inhibition. Our study, for the first time ascribes Smad6 a role in pancreatic cancer biology, which can be further explored for the development of novel therapeutic target.

Previous studies have shown Smad7 overexpression in pancreatic cancer cell lines [22-24]. Similar to our study, few other studies have shown a loss of Smad7 in patient samples $[24,25]$. This difference in expression in cell lines as compared to tissue samples might be because of a possible reversal of phenotype in artificial tissue culture systems. In our study, loss of Smad7 expression surpassed that of Smad4 and was absent in 56\% of tumor samples, which is quite close to what has been reported by Guo et al [24]. Amongst clinicopathological parameters, loss of Smad7 significantly correlated with both tumor size as well as margin status. On similar lines, Wang et al showed a significant correlation between the low Smad7 expression and lymph node metastasis [26]. These observations, put together, indicate a role for Smad7 in the aggressiveness of this disease. In fact, different studies have isolated different molecules, like KLF11, retinoblastoma, thioredoxin, which are involved in Smad7 dependent aggressiveness of pancreatic cancer $[23,27,28]$. However, unlike Wang et al, we did not find a significant correlation between loss of Smad7 and patient survival.

The smaller sample size in the study is acknowledged, the reasons being i) choice of prospective samples for the study, ii) low incidence of pancreatic cancer in Indian population: $0.5-2.4$ per 100000 men and 0.2-1.8 
Table 6 Summary of results of survival analysis by Kaplan-Meier test

\begin{tabular}{|c|c|c|c|c|c|c|}
\hline \multirow[t]{2}{*}{ Variables } & \multirow[t]{2}{*}{ Groups } & \multirow[t]{2}{*}{ No. of patients } & \multirow[t]{2}{*}{ Median } & \multicolumn{2}{|c|}{ 95\% Confidence Interval (Cl) } & \multirow[t]{2}{*}{ Significance } \\
\hline & & & & Lower & Upper & \\
\hline \multirow[t]{2}{*}{$\overline{\text { Age }}$} & $<50$ & 5 & $5.000 \pm 2.191$ & 0.706 & 9.294 & 0.211 \\
\hline & $\geq 50$ & 20 & $9.000 \pm 2.225$ & 4.639 & 13.361 & \\
\hline \multirow[t]{2}{*}{ Sex } & Male & 13 & $10.000 \pm 1.754$ & 6.562 & 13.438 & 0.127 \\
\hline & Female & 12 & $6.000 \pm 1.732$ & 2.605 & 9.395 & \\
\hline \multirow[t]{2}{*}{ Grade } & G1 & 13 & $7.000 \pm 1.198$ & 4.651 & 9.349 & 0.228 \\
\hline & $\overline{\mathrm{G} 2}$ & 12 & $10.000 \pm 1.125$ & 7.795 & 12.205 & \\
\hline \multirow[t]{2}{*}{ Stage } & $1+\|$ & 10 & $10.000 \pm 2.066$ & 5.951 & 14.049 & $0.031^{*}$ \\
\hline & III+IV & 15 & $7.000 \pm 0.949$ & 5.141 & 8.859 & \\
\hline \multirow[t]{2}{*}{ Tumor size } & $<3 \mathrm{~cm}$ & 19 & $9.000 \pm 0.933$ & 7.172 & 10.828 & 0.842 \\
\hline & $\geq 3 \mathrm{~cm}$ & 6 & 6.000 & - & - & \\
\hline \multirow[t]{2}{*}{ Margin status } & Negative & 22 & $9.000 \pm 1.038$ & 6.966 & 11.034 & 0.999 \\
\hline & Positive & 3 & 6.000 & - & - & \\
\hline \multirow[t]{2}{*}{ pSmad4 } & Absent/Low & 20 & $6.000 \pm 0.745$ & 4.539 & 7.461 & $0.003^{*}$ \\
\hline & Moderate/High & 5 & $13.000 \pm 2.191$ & 8.706 & 17.294 & \\
\hline \multirow[t]{2}{*}{ pSmad6 } & Absent/Low & 14 & $7.000 \pm 0.926$ & 5.185 & 8.815 & 0.141 \\
\hline & Moderate/High & 11 & $10.000 \pm 1.477$ & 7.105 & 12.895 & \\
\hline \multirow[t]{2}{*}{ pSmad7 } & Absent/Low & 20 & $7.000 \pm 2.236$ & 2.617 & 11.383 & 0.633 \\
\hline & Moderate/High & 5 & $10.000 \pm 3.286$ & 3.559 & 16.441 & \\
\hline
\end{tabular}

*The significant values are highlighted.

per 100000 women [29], iii) limited time for the collection of patient samples, iv) exclusion of archival samples due to poor and unreliable staining.

\section{Conclusions}

The present study strongly substantiates the previous reports in further establishing the role of Smad4 as a prognostic marker. It also suggests that a further exploration into the newly found roles for Smad6 and Smad7 in PDAC biology, with a larger sample size, may help discern some novel therapeutic targets for this disease, subsequently contributing to the improvement in therapeutic strategies and better disease management for PDAC patients.

\section{Acknowledgements and funding}

We are grateful to Indian Council of Medical Education and Research for providing the stipend (No. 3/1/3/2002-MPD-JRF) for PS to carry out this study as a part of her PhD work. We are thankful for Postgraduate Institute of Medical Education and Research for funding the study and providing the infrastructure.

\section{Author details}

${ }^{1}$ Department of General Surgery, Postgraduate Institute of Medical Education and Research, Chandigarh, India. ${ }^{2}$ Department of Cytology and Gynaecological Pathology, Postgraduate Institute of Medical Education and Research, Chandigarh, India. ${ }^{3}$ Department of Histopathology, Postgraduate Institute of Medical Education and Research, Chandigarh, India.

\section{Authors' contributions}

Author PS conducted the IHC experiments, compiled the data and drafted the manuscript. RS and BDR did IHC evaluation. JDW applied the biostatistics. RS, JDW and BDS helped in the design of study. All authors read and approved the final manuscript.

\section{Competing interests}

The authors declare that they have no competing interests.

Received: 24 May 2011 Accepted: 23 December 2011

Published: 23 December 2011

\section{References}

1. Wrana JL, Attisano L, Wieser R, Ventura F, Massague J: Mechanism of activation of the TGF-beta receptor. Nature 1994, 370:341-347.

2. Massague J: TGF-beta signal transduction. Annu Rev Biochem 1998, 67:753-791.

3. Souchelnytskyi S, Tamaki K, Engstrom U, Wernstedt C, ten Dijke $P$, Heldin CH: Phosphorylation of Ser465 and Ser467 in the C terminus of Smad2 mediates interaction with Smad4 and is required for transforming growth factor-beta signaling. J Biol Chem 1997, 272:28107-28115.

4. de Caestecker MP, Yahata T, Wang D, Parks WT, Huang S, Hill CS, Shioda T, Roberts AB, Lechleider RJ: The Smad4 activation domain (SAD) is a proline-rich, p300-dependent transcriptional activation domain. J Biol Chem 2000, 275:2115-2122.

5. de Winter JP, Roelen BA, ten Dijke $P$, van der Burg B, van den Eijnden-van Raaij AJ: DPC4 (SMAD4) mediates transforming growth factor-beta1 (TGF-beta1) induced growth inhibition and transcriptional response in breast tumour cells. Oncogene 1997, 14:1891-1899.

6. Hayashi H, Abdollah S, Qiu Y, Cai J, Xu YY, Grinnell BW, Richardson MA, Topper JN, Gimbrone MA, Wrana JL, Falb D: The MAD-related protein Smad7 associates with the TGFbeta receptor and functions as an antagonist of TGFbeta signaling. Cell 1997, 89:1165-1173.

7. Imamura T, Takase M, Nishihara A, Oeda E, Hanai J, Kawabata M, Miyazono K: Smad6 inhibits signalling by the TGF-beta superfamily. Nature 1997, 389:622-626.

8. Singh P, Srinivasan R, Wig JD: Major molecular markers in pancreatic ductal adenocarcinoma and their roles in screening, diagnosis, prognosis, and treatment. Pancreas 2011, 40:644-652. 
9. van Heek T, Rader AE, Offerhaus GJ, McCarthy DM, Goggins M, Hruban RH Wilentz RE: K-ras, p53, and DPC4 (MAD4) alterations in fine-needle aspirates of the pancreas: a molecular panel correlates with and supplements cytologic diagnosis. Am J Clin Pathol 2002, 117:755-765.

10. Hahn SA, Schutte M, Hoque AT, Moskaluk CA, da Costa LT, Rozenblum E, Weinstein CL, Fischer A, Yeo CJ, Hruban RH, Kern SE: DPC4, a candidate tumor suppressor gene at human chromosome 18q21.1. Science 1996, 271:350-353.

11. Schutte M, Hruban RH, Hedrick L, Cho KR, Nadasdy GM, Weinstein $C L$, Bova GS, Isaacs WB, Cairns P, Nawroz H, et al: DPC4 gene in various tumor types. Cancer Res 1996, 56:2527-2530.

12. Hruban RH, Goggins M, Kern SE: Molecular genetics and related developments in pancreatic cancer. Curr Opin Gastroenterol 1999, 15:404-409.

13. Hruban RH, Offerhaus GJ, Kern SE, Goggins M, Wilentz RE, Yeo CJ: Tumorsuppressor genes in pancreatic cancer. J Hepatobiliary Pancreat Surg 1998, 5:383-391.

14. Singh $P$, Wig JD, Srinivasan R: The Smad family and its role in pancreatic cancer. Indian J Cancer 2011, 48:351-360.

15. Katz MH, Hwang R, Fleming JB, Evans DB: Tumor-node-metastasis staging of pancreatic adenocarcinoma. CA Cancer J Clin 2008, 58:111-125.

16. Hua Z, Zhang YC, Hu XM, Jia ZG: Loss of DPC4 expression and its correlation with clinicopathological parameters in pancreatic carcinoma. World J Gastroenterol 2003, 9:2764-2767.

17. Biankin AV, Morey AL, Lee CS, Kench JG, Biankin SA, Hook HC, Head DR, Hugh TB, Sutherland RL, Henshall SM: DPC4/Smad4 expression and outcome in pancreatic ductal adenocarcinoma. J Clin Oncol 2002, 20:4531-4542.

18. Tascilar M, Offerhaus GJ, Altink R, Argani P, Sohn TA, Yeo CJ, Cameron JL, Goggins M, Hruban RH, Wilentz RE: Immunohistochemical labeling for the Dpc4 gene product is a specific marker for adenocarcinoma in biopsy specimens of the pancreas and bile duct. Am J Clin Pathol 2001 116:831-837.

19. Crane CH, Varadhachary GR, Yordy JS, Staerkel GA, Javle MM, Safran H, Haque W, Hobbs BD, Krishnan S, Fleming JB, et al: Phase II trial of cetuximab, gemcitabine, and oxaliplatin followed by chemoradiation with cetuximab for locally advanced (T4) pancreatic adenocarcinoma: correlation of Smad4(Dpc4) immunostaining with pattern of disease progression. J Clin Oncol 2011, 29:3037-3043.

20. Smith RA, Tang J, Tudur-Smith C, Neoptolemos JP, Ghaneh P: Meta-analysis of immunohistochemical prognostic markers in resected pancreatic cancer. Br J Cancer 2011, 104:1440-1451.

21. Itoh S, Landstrom M, Hermansson A, Itoh F, Heldin CH, Heldin NE, ten Dijke P: Transforming growth factor beta1 induces nuclear export of inhibitory Smad7. J Biol Chem 1998, 273:29195-29201.

22. Kleeff J, Ishiwata T, Maruyama H, Friess H, Truong P, Buchler MW, Falb D, Korc M: The TGF-beta signaling inhibitor Smad7 enhances tumorigenicity in pancreatic cancer. Oncogene 1999, 18:5363-5372.

23. Arnold NB, Ketterer K, Kleeff J, Friess H, Buchler MW, Korc M: Thioredoxin is downstream of Smad7 in a pathway that promotes growth and suppresses cisplatin-induced apoptosis in pancreatic cancer. Cancer Res 2004, 64:3599-3606.

24. Guo J, Kleeff J, Zhao Y, Li J, Giese T, Esposito I, Buchler MW, Korc M, Friess $\mathrm{H}$ : Yes-associated protein (YAP65) in relation to Smad7 expression in human pancreatic ductal adenocarcinoma. Int J Mol Med 2006, 17:761-767.

25. Kim YH, Lee HS, Lee HJ, Hur K, Kim WH, Bang YJ, Kim SJ, Lee KU, Choe KJ, Yang HK: Prognostic significance of the expression of Smad4 and Smad7 in human gastric carcinomas. Ann Oncol 2004, 15:574-580.

26. Wang P, Fan J, Chen Z, Meng ZQ, Luo JM, Lin JH, Zhou ZH, Chen H, Wang K, Xu ZD, Liu LM: Low-level expression of Smad7 correlates with lymph node metastasis and poor prognosis in patients with pancreatic cancer. Ann Surg Oncol 2009, 16:826-835.

27. Ellenrieder V, Buck A, Harth A, Jungert K, Buchholz M, Adler G, Urrutia R, Gress TM: KLF11 mediates a critical mechanism in TGF-beta signaling that is inactivated by Erk-MAPK in pancreatic cancer cells. Gastroenterology 2004, 127:607-620.

28. Boyer Arnold N, Korc M: Smad7 abrogates transforming growth factorbeta1-mediated growth inhibition in COLO-357 cells through functional inactivation of the retinoblastoma protein. J Biol Chem 2005, 280:21858-21866.
29. Gajalakshmi CK, Swaminathan R, Shanta V: A study on pancreatic cancer in Chennai (Madras), India. Cancer Lett 1998, 122:221-226.

doi:10.1186/1756-0500-4-560

Cite this article as: Singh et al:: A study of Smad4, Smad6 and Smad7 in Surgically Resected Samples of Pancreatic Ductal Adenocarcinoma and Their Correlation with Clinicopathological Parameters and Patient Survival. BMC Research Notes 2011 4:560.

\section{Submit your next manuscript to BioMed Central and take full advantage of:}

- Convenient online submission

- Thorough peer review

- No space constraints or color figure charges

- Immediate publication on acceptance

- Inclusion in PubMed, CAS, Scopus and Google Scholar

- Research which is freely available for redistribution

Submit your manuscript at www.biomedcentral.com/submit
Biomed Central 